\title{
Peran Eritropoetin pada Anemia Prematuritas
}

\author{
I Nyoman Sartika, Wayan Retayasa, Made Kardana, Ida Bagus Mudita \\ Bagian Ilmu Kesehatan Anak, Fakultas Kedokteran Universitas Udayana, RS Sanglah Denpasar
}

\begin{abstract}
Eritropoetin merupakan molekul glikoprotein yang terdiri dari 165 asam amino dan 4 gugus karbohidrat dengan berat molekul sekitar $34 \mathrm{k}$ dalton. Peran eritropoetin dalam produksi sel darah merah melalui meningkatkan survival, proliferasi dan diferensiasi dari progenitor eritroid pada sumsum tulang. Eritropoetin berikatan dengan reseptor selanjutnya terjadi aktivasi ras/mitogen intraselular yang berperan dalam proliferasi sel. Regulasi produksi eritropoetin adalah peran dari hypoxia-inducible transcription factor-1 (HIF-1). Pada bayi yang lahir prematur terjadi penurunan kadar $\mathrm{Hb}$ yang berlebihan dibandingkan dengan bayi cukup bulan. Banyak faktor yang mempengaruhi anemia prematuritas, salah satu di antaranya adalah kurang respon eritropoetin terhadap penurunan kadar $\mathrm{Hb}$. Penggunaan eritropoetin rekombinan mengurangi frekuensi transfusi darah dan meningkatkan retikulosit dengan cepat. Eritropoetin rekombinan belum merupakan standar pengobatan anemia prematuritas secara universal (Sari Pediatri 2008;9(6):375-80).
\end{abstract}

Kata kunci: eritropoetin, anemia, bayi prematur

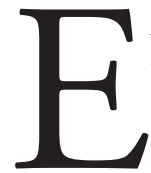

ritropoetin merupakan molekul glikoprotein yang terdiri dari 165 asam amino dan 4 gugus karbohidrat dengan berat molekul sekitar $34 \mathrm{k}$ dalton. Mempunyai dua ikatan disulfida, ikatan pertama antara asam amino sistein 6 dengan asam amino sistein 161 sedangkan ikatan kedua adalah asam amino sistein 29 dengan asam amino sistein 33. Sekitar 60\% molekul eritropoetin terdiri dari protein sedangkan sisanya adalah karbohidrat. ${ }^{1-5}$

Eritropoetin merupakan faktor pertumbuhan hematopoetik pertama yang dapat dibuat, yaitu

\footnotetext{
Alamat korespondensi

Dr. I Nyoman Sartika Bag/SMF Ilmu Kesehatan Anak FK UNUD/ RSUP Sanglah Denpasar Jln. Pulau Nias Denpasar Bali. Telepon/Fax: 0361-244038 atau 0361-257387 E-mail: Sartikapur2003@yahoo.com
}

eritropoetin rekombinan (epoetin alfa). ${ }^{4}$ Bersama dengan kemajuan teknologi DNA, eritropoetin rekombinan yang baru telah ditemukan yaitu Darbepoetin- $\alpha$ (NESP). Darbepoetin- $\alpha$ sedikit berbeda dengan eritropoetin aslinya. Darbepoetin- $\alpha$ memiliki berat molekul 38,5 k dalton, 5 rantai ikatan dengan oligosakarida dibandingkan 3 rantai oligosakarida pada eritropoetin aslinya, total karbohidrat 52\% dibandingkan $40 \%$ pada eritropoetin yang asli, mempunyai waktu paruh yang lebih panjang yaitu sekitar 48,8 jam dibandingkan 12-48 jam pada pemberian secara subkutan. Sedangkan ikatan reseptor pada tempat bekerja eritropoetin sama dengan eritropoetin asli. ${ }^{2}$

Pada tikus diperlukan sekitar 0,4 IU eritropoetin perhari untuk mempertahankan pruduksi sel darah merah, sedangkan pada manusia belum diketahui. Pada anemia atau hipoksia terjadi peningkatan kadar 
eritropoetin, yang pertama terjadi peningkatan adalah di ginjal selanjutnya sekitar 1 sampai 2 jam pada plasma. Hipoksia selama 15 sampai 30 menit sudah cukup untuk merangsang meningkatkan produksi eritropoetin. Puncak produksi terjadi sekitar 6 jam sampai 3 hari setelah kejadian hipoksia. Kadar eritropoetin berhubungan dengan keberadaan oksigen dan tergantung pada aktivitas proliferasi jaringan eritropoetik. ${ }^{3,6}$ Hipoksia merupakan stimulasi peningkatan produksi eritropoetin oleh ginjal. Pemberian transfusi yang sering akan berakibat penurunan produksi eritropoetin. Produksi eritropoetin berkurang akibat peningkatan hemoglobin dan sel darah merah yang mengangkut oksigen ke ginjal. Sekitar 10\% sampai 15\% produksi eritropoetin terjadi di luar ginjal. ${ }^{7,8}$

Eritropoetin mempunyai efek mitogenik terhadap burst forming units erythroid (BFU-E) dan colony forming units erythroid (CFU-E) serta memacu terjadi proliferasi. Eritropoetin dalam jumlah banyak seperti pada anemia terjadi peningkatan jumlah sel muda $B F U-E$, yang dimodulasi oleh berbagai hormonal dan faktor selular, seperti steroid androgenik. Eritropoetin tidak diperlukan pada maturasi eritroblas menjadi eritrosit. Peningkatan retikulosit makrositik dalam 24 jam setelah pemberian eritropoetin menandakan terjadi peningkatan eritropoesis. Eritropoetin juga menghambat pemecahan DNA dan kematian sel yang terprogram (apoptosis) melalui aktivasi p35.,3,6

\section{Eritropoesis pada janin dan neonatus}

Eritropoetin secara aktif terlibat pada eritropoesis janin sebagaimana dapat dideteksi dalam plasma, cairan amnion dan urin janin pada 30 minggu kehamilan. Eritropoetin pada darah janin meningkat sesuai dengan umur kehamilan. Kadar eritropoetin pada darah tali pusat dan cairan amnion lebih tinggi secara bermakna pada janin yang mengalami anemia dibandingkan dengan janin normal. Hati merupakan tempat utama produksi eritropoetin selama masa perkembangan janin. Secara bertahap terjadi perubahan tempat produksi eritropoetin dari hati menuju ginjal terjadi pada trimester ketiga kehamilan., ${ }^{5,6,8}$ Polisitemia pada bayi baru lahir merupakan respon terhadap hipoksia intrauterina. Selama minggu pertama kehidupan pada bayi yang normal terjadi penurunan eritropoesis. Penurunan kadar serum eritropoetin terjadi pada hari pertama sampai umur 2 bulan. Penekanan eritropoesis oleh karena perbaikan oksigenasi, penurunan produksi eritropoetin, dan penurunan respon produksi eritropoetin terhadap ketersediaan oksigen, selain itu kemungkinan adanya faktor inhibisi eritropoetin oleh estrogen. Kadar eritropoetin tali pusat berhubungan dengan umur kehamilan. Bayi dengan penyakit jantung sianotik dan bayi prematur dengan distress napas berat didapatkan kadar eritropoetin yang tinggi pada minggu pertama kehidupan. ${ }^{2,6}$

Peran eritropoetin pada produksi sel darah merah melalui peningkatan survival, proliferasi dan diferensiasi dari progenitor eritroid dalam sumsum tulang. Proses eritropoesis meliputi perubahan dari primitif multi poten hemopoetik stem sel menjadi myeloid stem sel kemudian menjadi colony forming units (CFU) GERM, BFU-E, kemudian menjadi colony forming units erythroid (CFU-E), normoblast, eritroblas, retikolosit, dan akhirnya menjadi eritrosit yang matur. Faktor pertumbuhan yang terlibat pada proses eritropoesis adalah granulocyte colony stimulating factor (G-CSF), interleukin (IL)-6, stem cell factor (SCF), IL-1, IL-3, IL-4,IL-9,IL-11, granulocyte-macrophage (GM)-CSF, insulin growth factor-1 $(I G F-1)$ dan eritropoetin. Titik tangkap utama eritropoetin pada sumsum tulang adalah pada colony forming units erythroid (CFU-E), yaitu menginduksi sel ini untuk proliferasi dan maturasi menjadi normoblas, retikulosit, dan menjadi sel eritrosit yang matur. Kerja eritropetin ini sinergis dengan SCF, GM-CSF, IL-3, IL-4, IL-9 dan IGF-1, bekerja merangsang maturasi dan diferensiasi $B F U-E$ dan $C F U-E$ menjadi normoblas pada perkembangan sel eritrosit. ${ }^{2-7}$

Eritropoetin berikatan dengan reseptor sel progenitor eritroid untuk regulasi sumsum tulang terhadap proliferasi, diferensiasi, dan survival sel eritroid. Penelitian menunjukkan sedikitnya terdapat 1000 reseptor setiap sel. Reseptor eritropoetin ini ditemukan pada sel eritroid dari tingkat $C F U-E$ sampai pronormoblas. Reseptor eritropoetin paling tinggi ditemukan pada $C F U-E$ dan pronormoblas. ${ }^{1,2,4}$ Jumlah reseptor eritropetin ini menurun secara bertahap selama diferensiasi sel eritroid. Penelitian menunjukkan bahwa retikulosit dan eritrosit yang matur tidak mengandung reseptor eritropoetin. ${ }^{1,2}$ Satu molekul eritropoetin akan mengikat dua reseptor pada permukaan sel sehingga terjadi proses dimerisasi. Langkah pertama dari intraseluler signaling adalah aktivasi dari Janus family of nonreceptor-type protein tyrosine kinases (Jaks), yaitu JAK2 tirosin kinase. Enzim JAK2 diketahui berhubungan 
dengan eritropoetin reseptor yang terletak berdekatan dengan transmembran. Apabila terjadi Delesi akan terjadi hambatan eritropoetin untuk menginduksi proliferasi sel. Setelah aktivasi reseptor terjadi proses fosforilasi 8 tirosine reseptor eritropoetin yang terletak pada sitoplasma. Fosforilasi tirosine ini merupakan tempat (docking site) untuk protein intraselular yang mengandung Scr homology 2 (SH2). Fosforilasi SH2 yang merupakan respon aktivasi eritropoetin mengakibatkan simulasi proliferasi sel eritroid (Gambar 1).,3,4

\section{Regulasi produksi eritropoetin}

Transkripsi faktor hypoxia inducible factor (HIF) berperan secara bermakna regulasi sel terhadap hipoksia. Pada sel yang tidak mengalami hipoksia tidak ditemukan protein $H I F-1 \alpha$, sedangkan sel yang terpapar hipoksia menunjukkan ekspresi dari protein HIF-1 $\alpha$ dalam 30 menit. Struktur molekul HIF-1 terdiri dari HIF-1 $\alpha$ dan HIF-1 $\beta$. HIF-1 $\beta$ merupakan aryl hydrocarbon nuclear translocator (ARNT) berperan pada xenobiotik. Beberapa penelitian menunjukkan penurunan konsentrasi O2 seluler akan terjadi peningkatan kadar HIF-1 $\alpha$. Regulasi HIF-1 $\alpha$ melibatkan sistem ubiquitin-proteosome. Terjadi destruksi $H I F-1 \alpha$ pada keadaan normoksia dan terjadi akumulasi bila terjadi hipoksia (Gambar 2).,3
Adenosin juga mempunyai peran yang sangat penting dalam produksi eritropoetin, cara kerja yang utama melalui $A$-kinase, C-kinase dan fosfolipase $A_{2}$. Hipoksia menyebabkan terjadi peningkatan kadar adenosin pada cairan ekstraselular, peningkatan dari adenosin ini terjadi peningkatan aktivitas dari ektonukleotidase. Peningkatan aktivitas ektonukleotidase menyebabkan terjadi peningkatan pemecahan ATP, peningkatan reseptor $A_{2 \mathrm{~A}}$ mRNA (Gambar 3). Aktivasi dari reseptor $A_{2 A}$ dan $A_{2 B}$ terjadi peningkatan

Adenilat siklase, cAMP, dan A-kinase. Peningkatan analog dari $c A M P$ akan terjadi peningkatan aktivitas $H I F-1 \alpha$ melalui aktivasi $A$-kinase. Aktivasi dari $C$ kinase melalui reseptor $A_{2 \mathrm{~B}}$ adenosin dan fosfolipase $\mathrm{A}_{2}$ mengakibatkan terjadi peningkatan ekspresi dari mRNA eritropoetin tanpa melalui transkripsi dari faktor HIF. Pemberian theopilin yang merupakan $\mathrm{A}_{1} \mathrm{~A}_{2}$ antagonis nonselektif reseptor adenosin pada tikus terjadi inhibisi produksi eritropoetin yang diinduksi oleh hipoksia. ${ }^{2,3,4}$

\section{Penggunaan eritropoetin pada anemia prematuritas}

Anemia pada bayi ditandai dengan konsentrasi hemoglobin serum rendah. Pada bayi prematur titik terendah kadar hemoglobin terjadi sekitar umur 8

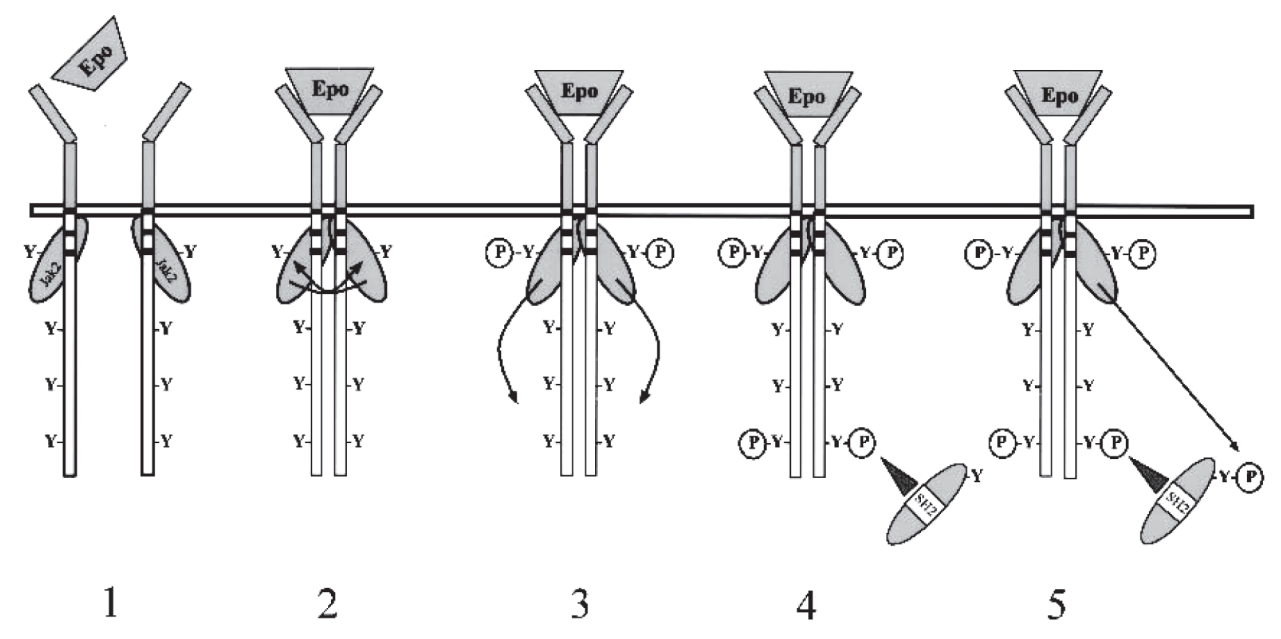

Gambar 1. Langkah pertama aktivasi reseptor eritropoetin yaitu dimerisasi (1), kontak berdekatan dari JAK2 kinase yang diaktivasi oleh transfosforilasi (2), fosforilasi dari tirosine reseptor eritropoetin $(3,4)$; memberikan docking sites untuk SH2.

Dikutip dari Fisher JW, 2003. ${ }^{2}$ 

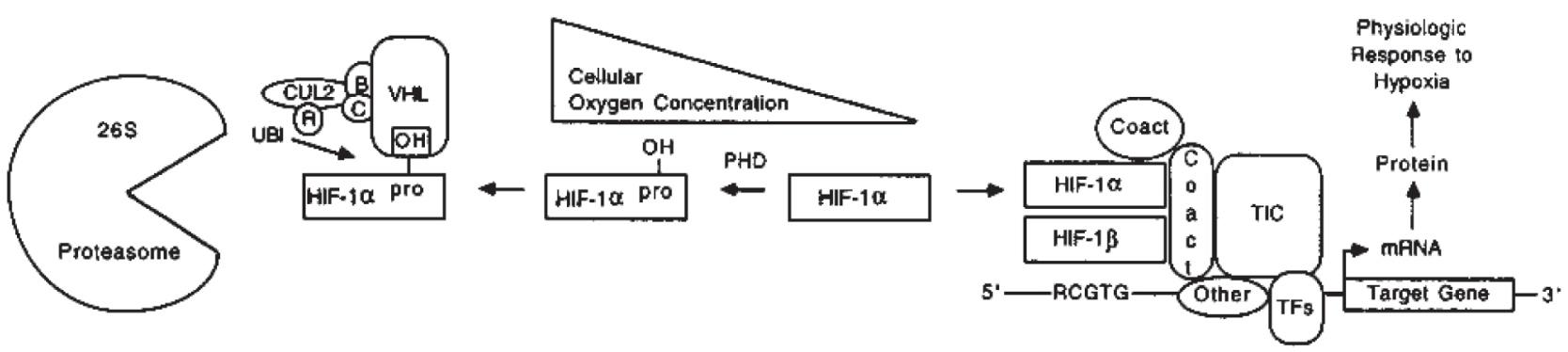

Gambar 2. Regulasi ekspresi $H I F-1 \alpha$ melalui konsentrasi $\mathrm{O}_{2}$ seluler.

Dikutip dari Fisher JW, 2003. ${ }^{2}$

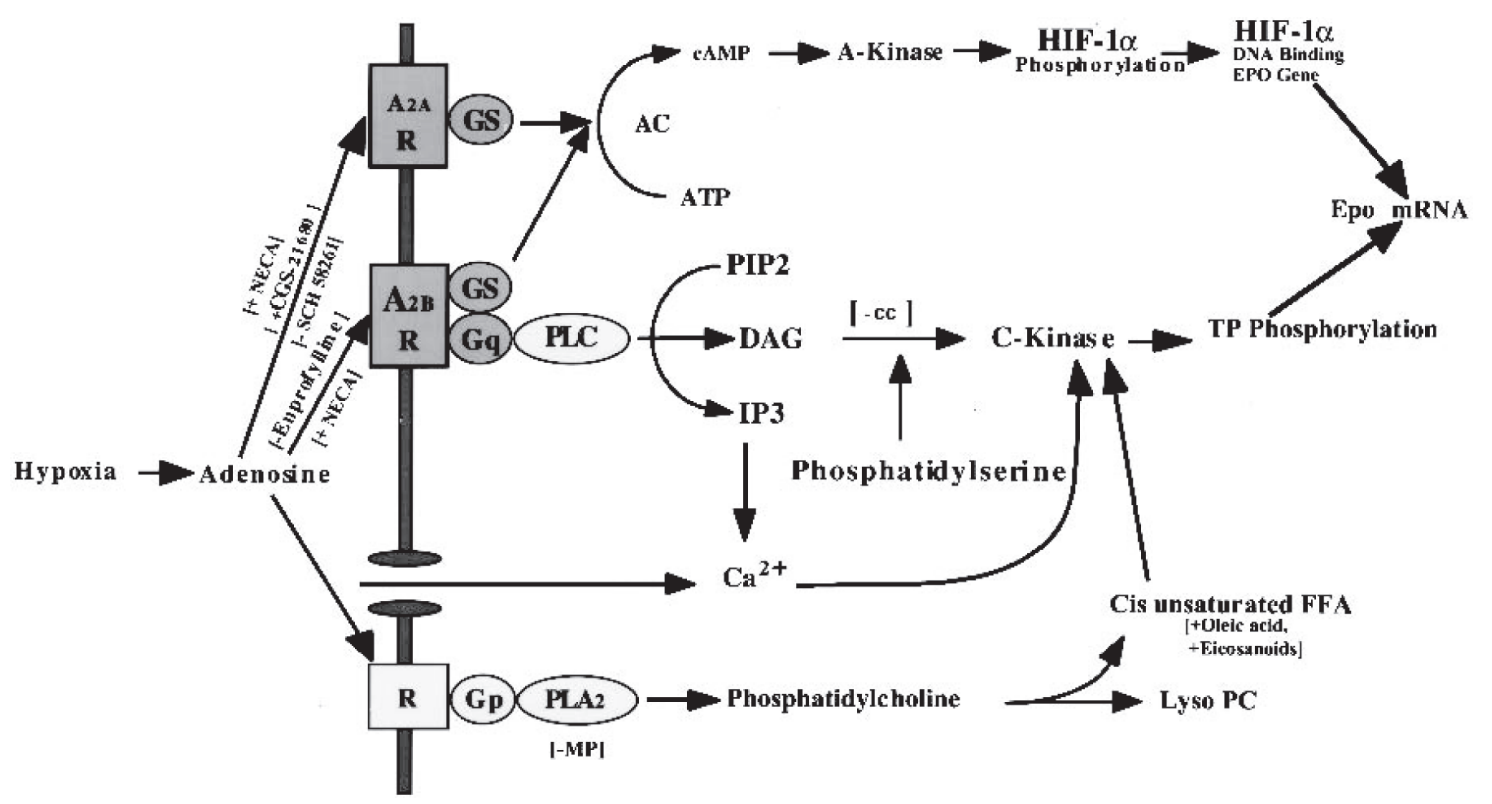

Gambar 3. Bagan mengenai peran adenosin protein A-kinase, C-kinase dan fosfolipase A dalam regulasi produksi eritropoetin pada keadaan hipoksia.

Dikutip dari Fisher JW, 2003. ${ }^{2}$

sampai 12 minggu, kadar hemoglobin pada bayi prematur terjadi penurunan lebih cepat dan lebih rendah 2 sampai $3 \mathrm{~g} / \mathrm{dl}$ dibandingkan dengan bayi cukup bulan. ${ }^{9-12}$ Anemia prematuritas terjadi pada bayi berat badan lahir rendah 1 sampai 3 bulan setelah lahir dengan kadar hemoglobin di bawah $7 \mathrm{mg} / \mathrm{dL}$. Derajat anemia dan kadar hemoglobin tergantung dari derajat prematuritas. Semakin kecil bayi semakin besar terjadi penurunan konsentrasi hemoglobin. Pada umur 2 bulan rerata kadar hemoglobin dapat mencapai 9,5 mg/dL pada bayi dengan berat badan lahir antara 1500 sampai 2000 gram dan $9,0 \mathrm{mg} / \mathrm{dL}$ pada bayi dengan berat badan lahir 1000 sampai 1500 gram. ${ }^{9,13}$

Tata laksana bayi anemia prematuritas meliputi transfusi darah, suplemen besi dan terapi eritropoetin rekombinan. Pemberian trasfusi darah tergantung dari berbagai faktor, di antaranya adalah kadar hemoglobin, keadaan kardiorespirasi, gejala dan tanda anemia. ${ }^{8,14,15}$ Eritropoetin baik produksi endogen atau pemberian dari luar mempunyai volume distribusi yang luas dan dieliminasi lebih cepat pada neonatus, berakibat keterbatasan waktu untuk stimulasi sumsum tulang. Atas dasar tersebut eritropoetin rekombinan digunakan untuk penatalaksanaan anemia prematuritas. ${ }^{6,8}$ 
Belum ada persetujuan yang konsisten mengenai waktu, dosis, cara pemberian, durasi pemberian terapi eritropoetin pada anemia prematuritas. ${ }^{7,8}$ Dosis eritropoetin rekombinan untuk pengobatan anemia prematuritas berkisar antara 75 sampai $1.200 \mathrm{IU} / \mathrm{kgbb} /$ minggu. Pengobatan eritropoetin rekombinan untuk bayi prematur dengan berat badan 750 sampai 1300 gram, dosis optimal adalah $250 \mathrm{IU} / \mathrm{kgbb}$ secara subkutan 3 kali seminggu mulai dari minggu pertama sampai keenam kehidupan. Suplementasi zat besi harus diberikan secara rutin pada pasien yang mendapat eritropoetin rekombinan pada 4 sampai 6 minggu pertama.,

Pemberian eritropoetin 2 kali seminggu dengan 5 kali seminggu pada bayi berat badan lahir sangat rendah dengan dosis mingguan yang sama, didapatkan hasil bahwa tidak ada perbedaan jumlah tranfusi darah yang diberikan antara kelompok yang mendapat terapi 2 kali seminggu dibandingkan dengan 5 kali seminggu. ${ }^{16}$ Pemberian eritropoetin $700 \mathrm{U} / \mathrm{kg} / \mathrm{minggu}$ pada bayi prematur dengan umur kehamilan kurang dari 33 minggu dan berat badan lahir kurang dari 1550 gram terjadi stimulasi eritropoesis dan secara bermakna terjadi pengurangan pemberian transfusi darah. ${ }^{15,17,18}$ Pemberian eritropoetin pada bayi prematur dengan berat badan di bawah atau sama dengan 1250 gram menunjukkan kadar feritin lebih rendah dibandingkan dengan yang tidak mendapat eritropoetin. ${ }^{18}$ Sedangkan pemberian eritropoetin pada bayi berat badan lahir amat sangat rendah tidak ada perbedaan volume tranfusi darah dibandingkan dengan yang tidak mendapat eritropoetin. ${ }^{19}$

Terapi diet juga penting pada tata laksana anemia prematuritas. Pasien harus mendapat asupan yang adekuat terhadap vitamin E, vitamin B-12, asam folat dan zat besi untuk mencegah berulang dan penurunan kadar hemoglobin pada bayi prematur. ${ }^{8,20,21}$ Pemberian vitamin E pada anemia prematuritas yang mendapat eritopoetin, perlu dosis yang tinggi untuk dapat meningkatkan respon eritropoesis. ${ }^{22}$

Toleransi penggunaan eritropoetin rekombinan cukup baik. Kejadian yang sangat jarang pernah dilaporkan adalah terbentuknya antibodi terhadap pasien yang mendapat eritropoetin rekombinan. ${ }^{7}$ Ditinjau dari rasio biaya dan keuntungan, eritropoetin belum merupakan standar pengobatan anemia prematuritas secara universal. Akan tetapi bila terdapat kontra indikasi untuk dilakukan tranfusi maka pemberian dari eritropoetin ini dapat dipertimbangkan. ${ }^{8}$

\section{Kesimpulan}

Eritropoetin berperan penting dalam produksi sel darah merah melalui peningkatan survival, proliferasi dan diferensiasi progenitor eritroid pada sumsum tulang. Eritropoetin juga berperan pada apoptosis dengan menurunkan kecepatan kematian sel progenitor eritroid. Penggunaan eritropoetin pada anemia prematuritas dapat mengurangi jumlah tranfusi. Namun ditinjau dari beban biaya dan keuntungan, eritropoetin belum merupakan standar pengobatan anemia prematuritas secara universal.

\section{Daftar Pustaka}

1. Lappin T. The cellular biology of erythropoietin receptors. The Oncologist 2003;8:15-8.

2. Fisher JW. Erythropoietin: physiology and pharmacology udate. Exp Biol Med 2003;228:1-14.

3. Sasaki R, Masuda S, Nagao M. Erythropoietin: multiple physiological functions and regulation of biosynthesis. Biosci biotechnol biochem 2000;64:1775-93.

4. Lacombe C, Mayeux P. The molecular biology of erythropoietin. Nephrol Dial Transplant 1999;14:22-8.

5. Moritz KM, Lim GB, Wintour EM. Developmental regulation of erythropoietin and erythropoiesis. Am J Physiol 1997;273:1829-44.

6. Baehner RL. Erythropoietin. Dalam: Miller DR, Penyunting. Blood of Infancy and Childhood. Edisi ke7. Philadelphia: Mosby; 1995. h. 148-52.

7. Cazzola M, Mercuriali F, Brugnara C. Use of recombinant human erythropoietin outside the setting of uremia. Blood 1997;89:4248-67.

8. Southgate WM. Anemia of prematurity. Diambil dari URL: http://www.emedicine.com/ped/tropic 2088.htm. Diakses tanggal 7 Juli 2005.

9. Ohls RK, Christensen RD. Development of the hematopoietic system. Dalam: Behrman RE, Kliegman RM, Jenson HB, penyunting. Nelson Texbook of Pediatrics. Edisi ke-17. Philadelphia: Saunders; 2004. h. 1600-1.

10. Mallouh AA. Anemia in the Newborn. Dalam: Elzouki AY, Harfi HA, Nazer HM, penyunting. Textbook of Clinical Pediatrics. Philadelphia: Lippincott Williams \& Wilkins; 2001. h. 239-40.

11. Thilo EH, Rosenberg AA. The Newborn Infant. Dalam: Hay WW, Hayward AR, Levin MJ, Sondheimer JM, penyunting. Current pediatric diagnosis and treatment. Edisi ke-16. Singapore: McGraw-Hill; 2003. h. 37-8. 
12. Alkalay AL, Galvis S, Ferry DA, Simmons CF, Krueger RC. Hemodynamic changes in anemia premature infants: are we allowing the hematocrits to faal too low? Pediatrics 2003;112:838-45.

13. Andersen C. Critical haemoglobin thresholds in premature infants. Arch Dis Child Fetal Neonatal Ed 2001; 84:146-8.

14. Bifano EM. Traditional and nontraditional approaches to the prevention and treatment of neonatal anemia. NeoReviews 2000;1:69-73.

15. Meyer MP, Sharma E, Carsons M. Recombinant erythropoietin and blood transfusion in selected preterm infants. Arch Dis Child Fetal Neonatal Ed 2003;88:415.

16. Brown MS, Keith JF. Comparison between two and five doses a week of recombinant human erythropoietin for anemia of prematurity: a randomized trial. Pediatrics 1999;104:210-5.

17. Rocha VLL, Benjamin ACW, Procianoy RS.The effect of recombinant human erythropoietin on the treatment of anemia of prematurity. J Pediatr 2001;77:75-83.
18. Ohls RK, Ehrenkranz RA, Wright LL. Effects of early erythropoietin therapy on the transfusion requirements of preterm infants below 1250 grams birth weight: a multicenter, randomized, controlled trial. Pediatrics 2001;108:934-42.

19. Franz AR, Pohlandt F. Red blood cell transfusion in very and extremely low birthweight infants under restrictive transfusion guidelines: is exogenous erythropoietin necessary?. Arch Dis Child Fetal Neonatal Ed 2001;84:96100.

20. Donato H, Vain N, Rendo P. Folate and vitamin B12 supplementation in very low birth weight infants treated with erythropoietin: a cautionary note. Pediatrics 2001;108:217.

21. Pollak A, Hayde M, Hayn M. Effect of intravenous iron supplementation on erythropoiesis in erythropoietintreated premature infants. Pediatrics 2001;107:78-85.

22. Pathak A, Rath P, Piscitelli J, Johnson L. Effects of vitamin E supplementation during erythropoietin treatment of the anemia of prematurity. Arch Dis Child Fetal Neonatal Ed 2003;88:324-8. 